\title{
Pharmacogenetics: Knowledge assessment amongst Syrian pharmacists and physicians
}

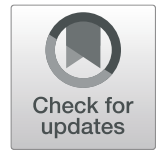

Lina Albitar ${ }^{1}$ and Ghalia Abou Alchamat ${ }^{2 *}$

\begin{abstract}
Background: Pharmacogenetics targets genetic variations that influence drug response. It is relatively a new science that has not been vastly employed in most developing countries including Syria. Therefore we aimed at evaluating the depth of knowledge in pharmacogenetics and the attitude towards it amongst Syrian pharmacists and physicians.

Methods: We carried out an internet-based questionnaire consisted of 26 questions, sent through specialized websites and private groups with a large number of pharmacists and physicians members. The survey was available online for a period of 1 month.

Results: The total number of respondents was 154, mostly female pharmacists. Our statistical analysis showed a strong positive association between profession (in favour of pharmacists) and pharmacogenetics knowledge $p=$ 0.049; however, no correlation with experience $p=0.811$ was found. A significant difference was reported between the knowledge of pharmacists and physicians $p=0.001$ concerning drugs that need pharmacogenetics testing before being prescribed. The majority of respondents had no information about applying genetic tests in Syria before prescribing medications nor did they possess the knowledge regarding drugs that show differential responses in patients according to their unique genotypes. In our study, the percentage knowledge assessment score was low in general (mean \pm Standard deviation, SD) $(46 \% \pm 13.9 \%)$. The majority of the respondents agreed that pharmacists should provide counselling to patients on the subject of pharmacogenetics. Respondents' opinions varied concerning making pharmacogenetics learning a priority.
\end{abstract}

Conclusion: Lack of pharmacogenetics knowledge was found amongst respondents in general. Our findings raise concerns about the lack of awareness amongst physicians, which may hinder the implementation of this crucial field in Syria. We suggest an emphasis on the role of education, training, and conducting genotyping research on the Syrian population.

Keywords: Pharmacogenetics, Pharmacogenetic testing, Drug response, Genetic variations, Knowledge assessment

\section{Introduction}

Personalized medicine (PM) became the method of choice ever since the human genome project (HGP) has been completed [1-4]. Pharmacogenetics (PGx) is the study of genetic variations that lead to differences in drug response $[5,6]$. The cytochrome $\mathrm{P} 450$ genes family

\footnotetext{
* Correspondence: dr.ghalia-aboualchamat@hotmail.com

${ }^{2}$ Department of Biology, Faculty of Science, Damascus University, Damascus, Syria

Full list of author information is available at the end of the article
}

are responsible for the metabolism of more than $20 \%$ of medications. Individuals with fewer or non-functional CYP2D6 genes are classified as slow metabolizers; therefore, when they take medications their drug levels may exceed the therapeutic range. In contrast, those with multiple copies of the same gene are classified as rapid metabolizers accordingly, the therapeutic effect of drugs may not be achieved $[1,7]$. Many physicians usually depend on the process of trial and error in treating their patients [8]. According to Klein et al., the average

C The Author(s). 2021 Open Access This article is licensed under a Creative Commons Attribution 4.0 International License, which permits use, sharing, adaptation, distribution and reproduction in any medium or format, as long as you give appropriate credit to the original author(s) and the source, provide a link to the Creative Commons licence, and indicate if changes were made. The images or other third party material in this article are included in the article's Creative Commons licence, unless indicated otherwise in a credit line to the material. If material is not included in the article's Creative Commons licence and your intended use is not permitted by statutory regulation or exceeds the permitted use, you will need to obtain permission directly from the copyright holder. To view a copy of this licence, visit http://creativecommons.org/licenses/by/4.0/ The Creative Commons Public Domain Dedication waiver (http://creativecommons.org/publicdomain/zero/1.0/) applies to the data made available in this article, unless otherwise stated in a credit line to the data. 
physician is not likely to have the awareness about the need to use PGx testing because of poor knowledge, training, and experience [9]. Due to the large genetic variations in drug response amongst individuals, it becomes essentially crucial to predict drug safety and efficacy and also shows the vital part PGx practice plays in the success of drug therapy [10-14]. PGx practice has been successfully employed in several developed countries to improve PM and advance clinical outcomes while in developing countries this has not been fully achieved yet $[9,15,16]$. Furthermore, there is a scarcity of PGx awareness/ knowledge in the Arab world in general $[17,18]$. This study was designed to assess PGx knowledge of Syrian physicians and pharmacists. In addition, it intended to evaluate their attitudes towards PGx and decide the preferred learning format for their future education in this field.

\section{Methods}

\section{Study design and the questionnaire}

A descriptive assessment was conducted on a cohort of pharmacists and physicians. We carried out an internetbased survey using Google form platform. The survey was adapted from literature reviews and validated questionnaires used for a similar purpose [19-22]. The first draft of the questionnaire was piloted on a small group of healthcare specialists. The assessment was established for simplicity and clarity to understand and answer. The validated survey was uploaded to websites and private groups for pharmacists and physicians, selected specifically for their large number of members (Supplement 1). Participation in the survey was voluntarily however, informed consents were obtained from all respondents before they have participated in the survey. The uploaded questionnaire began with an introduction about PGx and the aim of the study, followed by three separate sections that contained close-ended questions (Supplement 2 ). The first section included four questions regarding general information about the respondents, the second consisted of 18 questions inspecting knowledge assessment of PGx, and the third contained four questions foreseeing personal attitude towards this field. The survey was opened for 1 month (May to June 2020).

\section{Statistical analysis}

The statistical analyses were performed using IBM SPSS Statistics for Windows (version 23). Descriptive and comparative tests were used in data analysis. The percentage knowledge score (PKS) was tested for chosen questions (15 and 16) to evaluate the depth of respondents' knowledge and, was expressed as means (SD). Scores were calculated as one point for each correct answer and zero for the incorrect ones. The correct answers were calculated and the proportion of the average knowledge and its deviation was found. To evaluate perceptions and confidence, data from recorded responses were compared between physicians and pharmacists using Chi-square tests where applicable. A significance level of $p<0.05$ was considered statistically significant. Cramer's V correlation coefficient was used in measuring the strength or weakness of the relationship between two variables.

\section{Results \\ Section one \\ General information about the respondents}

The total number of respondents was 154, mostly females $(66.2 \%, 102)$, while the number of male respondents was almost the half $(33.8 \%, 52)$. Responders were in three groups, pharmacists $(48 \%, 74)$, physicians $(33.1 \%, 51)$ and a group of academics $(18.8 \%, 29)$ named "others". The majority of respondents were less than 30 years old $(48.7 \%, 75)$ and still under training $(30.5 \%, 47)$, or having less than 5 years of experience $(27.9 \%, 43)$. The lowest percentages of professions participated in the survey were for physicians under specialization (14.3\%, 22 ) and pharmacists working in pharmaceutical companies $(10.4 \%, 16)$. All the other professions were approximately equal amongst respondents $(18.8 \%, 29)$ (Table 1$)$.

\section{Section two \\ Familiarity with the terms "genetics and PGX"}

Analyzing results revealed that $44.2 \%$ of the respondents were not familiar with the concept of genetics and $35.1 \%$ were not sure of their knowledge (Table 2). No correlation was found between knowledge of genetics and profession $(p=0.52)$. However, a strong positive association was found between knowledge and experience $(p=0.01)$, Cramer's V. was 0.2. A large percentage of respondents have confirmed that they have heard of the term "PGx" before $(59.7 \%, 92)$, mainly at university $(40.9 \%)$. The percentage of the pharmacists who have heard of the term "PGx" was $71.6 \%$ while the percentages of the physicians and academics were only 45 and $55.2 \%$ respectively. In addition, the percentage of physicians unsure of that term was almost twice that of pharmacists $13.7 \%$ versus $6.8 \%$ (Table 3). Furthermore, a small percentage of the respondents $10.4 \%(16 / 154)$ stated that they have heard of the Clinical Pharmacogenetics Implementation Consortium (CPIC), while the majority $60.4 \%$ (93/154) declared that they have never heard of it. No response was obtained from the remaining participants 29.2\% (45/ 154).

\section{Respondents' knowledge of $P G x$}

A substantial percentages of participants $28.6 \%(44 / 154)$ did not respond to the question about their knowledge of PGx. The majority of respondents who did respond 
Table 1 Characteristics of the respondents participating in the study

\begin{tabular}{|c|c|c|c|}
\hline \multirow[t]{2}{*}{ Gender } & \multirow[t]{2}{*}{ Number (\%) } & Male & $52(33.8 \%)$ \\
\hline & & Female & $102(66.2 \%)$ \\
\hline Age & \multirow[t]{8}{*}{ Mean (SD) } & & $32.7(9.7)$ \\
\hline Experien & & & $11.7(9.2)$ \\
\hline \multirow[t]{6}{*}{ Professic } & & Community Pharmacist & $29(18.8 \%)$ \\
\hline & & Pharmacist working in a pharma company & $16(10.4 \%)$ \\
\hline & & Pharmacist under specialization & $29(18.8 \%)$ \\
\hline & & Physician under specialization & $22(14.3 \%)$ \\
\hline & & Specialist physician working at a clinic or hospital & $29(18.8 \%)$ \\
\hline & & Other & $29(18.8 \%)$ \\
\hline
\end{tabular}

were pharmacists $52.7 \%$ (58/110). Interestingly, only $10 \%$ of the respondents $(11 / 110)$ stated that they have good knowledge of PGx, ten of them were pharmacists, (Table 4). Our statistical analysis indicated a very strong positive association between profession and knowledge of PGx $p=0.049$, Cramer's V was 0.3 , but no correlation was found with experience $p=0.811$. Furthermore, the majority of the respondents, $83.8 \%$ (129/ 154), agreed that genetic variations influence the response to drugs, more than half of them were pharmacists 51.1\% (66/ $129)$, and were under training 30.2\% (39/129). Our statistical analysis showed a significant correlation with profession $p=0.008$ and also with gender $p<0.05$.

\section{PGX testing and its impact on prescribing medications}

Our findings showed that $63.1 \%$ of the respondents declared that they did not have any sufficient knowledge about PGx testing, while less than one-fifth of the respondents either knew about it $18.9 \%$ or were not sure of their knowledge 18\%. (Table 5). A strong positive association was found between the knowledge of PGx testing and experience $p=0.055$, Cramer's V was 0.2 , while no significant association was found with profession $p=$ 0.469. Additionally, our results illustrated that $48.7 \%$
(75/154) of the respondents could not identify or were not sure $32.5 \%(50 / 154)$ of drugs that need PGx testing before being prescribed. Only 18.8\% (29/154) have stated that they could, few of those were from the physicians' group $13.8 \%(4 / 29)$ versus the majority which was from the pharmacists' group $72.4 \%$ (21/29). Statistical analysis showed a significant difference between knowledge of pharmacists and physicians $p=0.001$. However, no significant correlation was found between knowledge and gender $p=0.57$. Furthermore, our data showed that $87 \%$ $(134 / 154)$ of the respondents agreed on the role of PGx testing in minimizing drug side effects and determining the personal suitable dose. The other respondents either did not agree 5.2\% (8/154) or were not sure $7.7 \%(12 / 154)$. No significant association was found with experience $p=0.39$ or gender $p=0.44$; however, a significant correlation was found with profession $p=0.04$. A substantial percentage of respondents 59.7\% (92/ 154) had no information about applying PGx tests in Syria before prescribing medications, while $26.6 \%(41 / 154)$ were not sure. Interestingly, pharmacists were more knowledgeable of these tests than physicians 19\% (14/74) versus 6\% (3/51), respectively.

Table 2 Respondents' knowledge of genetics

\begin{tabular}{|c|c|c|c|c|}
\hline & & Yes & No & Not sure \\
\hline \multirow[t]{6}{*}{ Profession } & Community Pharmacist & 8 & 11 & 10 \\
\hline & Pharmacist working in a pharma company & 6 & 7 & 3 \\
\hline & Pharmacist under specialization & 6 & 12 & 11 \\
\hline & Physician under specialization & 4 & 10 & 8 \\
\hline & Specialist physician working at a clinic or hospital & 2 & 17 & 10 \\
\hline & Other & 6 & 11 & 12 \\
\hline \multirow[t]{4}{*}{ Experience } & Under training & 6 & 18 & 23 \\
\hline & Less than 5 years & 7 & 23 & 13 \\
\hline & Between 5 and 10 years & 10 & 12 & 2 \\
\hline & More than 10 years & 9 & 15 & 16 \\
\hline Total No. (\%) & & $32(20.7 \%)$ & 68 (44.2\%) & $54(35.1 \%)$ \\
\hline
\end{tabular}


Table 3 Respondents' knowledge of PGx term

\begin{tabular}{|c|c|c|c|c|}
\hline & Yes & & No & Not sure \\
\hline \multirow[t]{6}{*}{ Profession } & Community Pharmacist & 20 & 6 & 3 \\
\hline & Pharmacist working in a pharma company & 13 & 3 & 0 \\
\hline & Pharmacist under specialization & 20 & 7 & 2 \\
\hline & Physician under specialization & 9 & 11 & 2 \\
\hline & Specialist physician working at a clinic or hospital & 14 & 10 & 5 \\
\hline & Other & 16 & 9 & 7 \\
\hline Total No. (\%) & $92(59.7 \%)$ & & $46(29.8 \%)$ & $16(10.4 \%$ \\
\hline
\end{tabular}

\section{Patient's phenotype role and its impact on medications}

The majority of respondents $76 \%$ (117/154) agreed that there is a role for the patient's phenotype (slow, medium, rapid) in determining the appropriate drug dosage. While 15\% (23 /154) were not sure. However, a few stated it has no role at all 9.1\% (14/154) (Table 6). Our statistical analysis revealed a significant difference between this specific knowledge and gender $p<0.005$; most female respondents answered the question correctly in comparison to male respondents. Additionally, a significant association was found with the profession, in favour of pharmacists $p=0.003$. Moreover, the majority of respondents, $61 \%(94 / 154)$, did not know the significance of "Poor Metabolizer Phenotype"; therefore, they answered the question incorrectly, while $14.3 \%$ (22/ $154)$ were not sure. Only $24.7 \%$ (38/154) answered the question correctly, mainly were pharmacists with less than five years of experience. Thus significant differences were found between the respondents correct answers and their professions $p=0.02$. No significant difference was detected with gender $p=0.10$. Furthermore, $32.5 \%$ $(50 / 154)$ of the participants responded correctly to the question about the association between a slowmetabolizer phenotype and a drug that acts as a catalyst for CYP2D6 enzyme activity, 28\% (14/50) of them were under training. Significant differences were found between the knowledge of pharmacists and physicians in favour of pharmacists $p=0.008$, and also between gender $p=0.05$.

\section{Taking medical history before prescribing medications}

Our results showed that approximately one-third of the respondents $33.1 \%(51 / 154)$ often ask about personal and family history before prescribing medications, while $27.9 \%$ (43/154) of them ask only depending on the case (Fig. 1). Statistical analysis indicated significant differences with experience $p<0.05$, profession $p=0.003$ and gender $p=0.01$.

\section{Patient's genotype and its impact on medication and mechanisms}

Percentage knowledge assessment score, PKS for question 15 about drugs, which may show differential response in patients according to their unique genotype was low in general, (mean \pm Standard deviation, SD) (46\% $\pm 13.9 \%)$. In addition, the PKS calculation for the Pharmacists' group only, was $48.9 \% \pm 15.3 \%$ and for the physicians' group only was $41.2 \% \pm 10.8 \%$ indicating also a low level of Knowledge. A significant association was

Table 4 The PGx knowledge amongst respondents

\begin{tabular}{lllll}
\hline & & Good Knowledge & Little Knowledge & No Knowledge \\
\hline Profession & Community Pharmacist & 2 & 17 & 3 \\
& Pharmacist working in a pharma company & 3 & 10 & 0 \\
& Pharmacist under specialization & 5 & 16 & 2 \\
& Physician under specialization & 1 & 9 & 5 \\
& Specialist physician working at a clinic or hospital & 0 & 12 & 5 \\
\multirow{3}{*}{ Experience } & Other & 0 & 25 & 8 \\
& Under training & 2 & 21 & 6 \\
& Less than 5 years & 2 & 12 & 3 \\
Total No. (\%) & Between 5 and 10 years & 3 & 20 & $\mathbf{2 1}$ \\
\hline
\end{tabular}


Table 5 Participants' response to their knowledge of PGx testing

\begin{tabular}{|c|c|c|c|c|}
\hline & & Yes & No & Not sure \\
\hline \multirow[t]{6}{*}{ Profession } & Community Pharmacist & 5 & 14 & 3 \\
\hline & Pharmacist working in a pharma company & 5 & 5 & 3 \\
\hline & Pharmacist under specialization & 6 & 13 & 4 \\
\hline & Physician under specialization & 1 & 11 & 4 \\
\hline & Specialist physician working at a clinic or hospital & 2 & 14 & 2 \\
\hline & Other & 2 & 13 & 4 \\
\hline \multirow[t]{4}{*}{ Experience } & Under training & 4 & 25 & 6 \\
\hline & Less than 5 years & 6 & 13 & 10 \\
\hline & Between 5 and 10 years & 6 & 11 & 1 \\
\hline & More than 10 years & 5 & 21 & 3 \\
\hline Total No. (\%) & & 21 (18.9\%) & 70 (63.1\%) & $20(18 \%)$ \\
\hline
\end{tabular}

found between the two above professions $p=0.001$. It is noteworthy to point out that 99 respondents (64.2\%) were not confident of their answers and have selected the option "not sure" in addition to their affirmative answers. Furthermore, when participants were asked about the common mechanisms that affect drug response and are influenced by one's genotype (question 16), our results showed that only $1.9 \%(3 / 154)$ of the respondents replied correctly (chose all four options), whereas only $19.5 \%$ (30 /154) responded correctly to two out of the four options or to one correct option only 44.8\% (69 /154). PKS was $28.2 \% \pm 23.9 \%$ indicating a weak knowledge. Remarkably, only three respondents $1.9 \%(3 / 152)$ reacted correctly to the question about the estimated percentage of prescribed medications metabolized by genetically varied enzymes, Whereas, most of the respondents $54.6 \%(83 / 152)$ stated that they were not sure.

\section{Section three}

\section{Personal attitude towards PGX}

Our results revealed that $69.5 \%(107 / 154)$ of the respondents agreed that pharmacists should provide some genetic counselling to patients before dispensing prescriptions. Furthermore, $72.72 \%(112 / 154)$ of the respondents favored performing PGx testing to predict drug efficacy before prescribing appropriate medications, $47.3 \%$ (53/112) of them were pharmacists and 33\% (37/ 112) were physicians. Respondents 'opinions varied regarding making PGx learning a priority as shown in Fig. 2. No significant correlation was found between desire to learn and profession $P=0.6482$. When asked about the best approach to increase knowledge of PGx, responses varied amongst participants; the majority (42.9\%) chose college education. However, others chose specialized courses $(20.8 \%)$, conferences $(18.8 \%)$, online courses $(11.7 \%)$, and only $5.2 \%$ preferred specialized journals.

\section{Discussion}

The science of pharmacogenetics is relatively new in the Middle East. Our study is one of a few in the Arab world to demonstrate the level of knowledge and attitude towards PGx amongst physicians and pharmacists. A survey of 26 questions was sent to professional groups with

Table 6 Participants' response to the role of patient's phenotype and its impact on medication

\begin{tabular}{|c|c|c|c|c|}
\hline & & Yes & No & Not sure \\
\hline \multirow[t]{6}{*}{ Profession } & Community Pharmacist & 21 & 4 & 4 \\
\hline & Pharmacist working in a pharma company & 15 & 0 & 1 \\
\hline & Pharmacist under specialization & 26 & 1 & 2 \\
\hline & Physician under specialization & 14 & 3 & 5 \\
\hline & Specialist physician working at a clinic or hospital & 19 & 6 & 4 \\
\hline & Other & 22 & 0 & 7 \\
\hline \multirow[t]{4}{*}{ Experience } & Under training & 37 & 5 & 5 \\
\hline & Less than 5 years & 34 & 1 & 8 \\
\hline & Between 5 and 10 years & 17 & 3 & 4 \\
\hline & More than 10 years & 29 & 5 & 6 \\
\hline Total No. (\%) & & 117 (75.9\%) & 14 (9.1\%) & 23 (14.9\%) \\
\hline
\end{tabular}




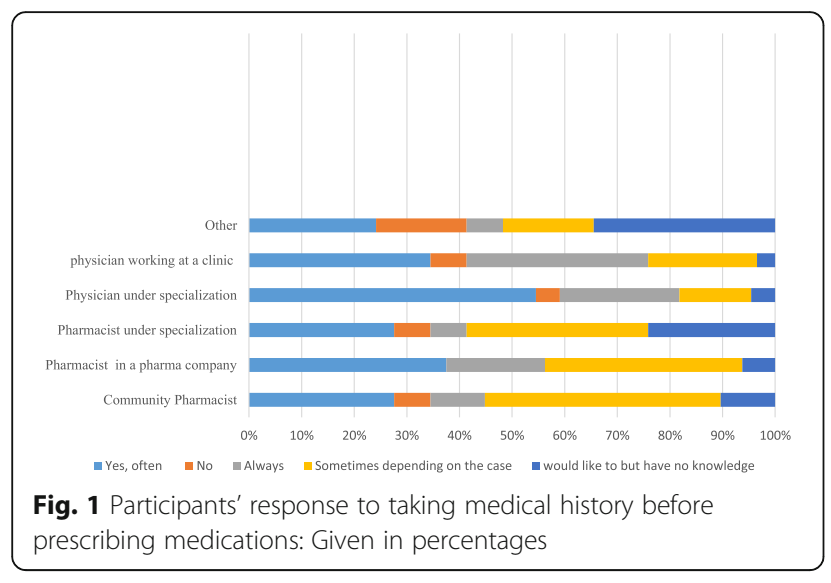

a large number of members, and was left available for 1 month, only 154 people responded. This weak participation rate may reflect a lack of general interest in PGx or/ and knowledge. However, almost all respondents who started the questionnaire completed it (152/154), which may indicate that those who responded were interested in the topic of PGx in particular. The respondents in our study, were mostly females (66.2\%), pharmacists (48\%), less than 30 years old $(48.7 \%)$ and still under training (30.5\%). These findings may reflect pharmacists curiosity especially young and under training towards the studied topic in comparison to physicians and other respondents. Our results were similar to previous studies conducted in UAE and Qatar, [23, 24] yet distinct from those reported in a prior study in Kuwait [20], where most participants were males and physicians.

Our data showed that the majority of respondents have heard the PGx term mainly at university. PGx is taught in Syria to first-year students at medical and pharmacy colleges. Additionally, pharmacy students are exposed to PGx education during advanced college years. The difference in the curriculum may explain why the percentage of pharmacists who were familiar with this scientific term was twice that of physicians. Divergence in medical curricula is not limited to Syria, it is

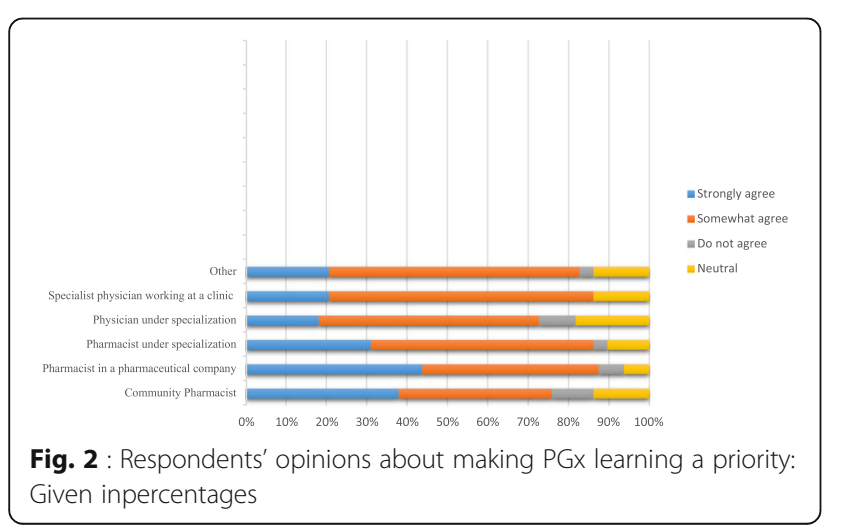

universal [25], and in general PGx education is still poor [26-30]. In our study, the influence of the profession was more significant in the knowledge of PGx in particular but not towards PGx testing awareness for which the experience had a larger impact. Furthermore, our findings demonstrated that younger age and less experienced professionals had the highest PGx knowledge, these results are in line with the study of Rahma et al [23] however they are inconsistent with the findings of some previous studies [20,24] where the influence of experience was dominant.

In our study, pharmacists were more informed about specific knowledge regarding the patient's phenotype, genotype and their impact on medications in comparison with physicians. However, when particular knowledge was evaluated concerning specific drugs that demonstrate differential responses in patients according to their unique genotypes, $64.2 \%$ of respondents were not confident in their answers. Poor knowledge became clearer when we intentionally did not indicate the possibility of choosing more than one answer when asked about the mechanisms that affect drugs responses and are influenced by different genotypes.

Furthermore, positive responses were evident amongst pharmacists than physicians towards the significance of PGx; its application into their practice; PGx testing; and the role of PGx in effective therapy. These outcomes are similar to those found in previous studies $[20,24,31$, 32] where positive attitude was more common amongst pharmacists. Likewise, more than two-thirds of the respondents $(69.5 \%)$ approved the role of pharmacists in providing counselling to patients on the subject of PGx. This result is consistent with the reports by prior studies, where the majority agreed on the important role pharmacists play [20, 33-35].

In addition, the majority of respondents (72.72\%) in our study were in favour of performing PGx testing before prescribing appropriate medications. This outcome is in agreement with the European Ubiquitous Pharmacogenomics (U-PGx) report [22] and the study of Stanek et al., in the USA [29]. However, agreeing may not reflect ability as in a report from a Dutch survey, only $27 \%$ of respondents declared fit for interpreting PGx testing results and provide related advice to patients [36].

Moreover, our data showed a lack of consensus regarding making learning more about PGx a priority. Nevertheless, the majority agreed on college education as the best approach.

This study demonstrated that professionals, especially physicians, who are in direct contact with patients have limited knowledge of PGx, yet it seems a widespread problem [37-40]. Poor knowledge of this field extends to some of the most recognized developed countries, for example in a combined study between Japan and USA to 
assess the knowledge of pediatricians, less than $20 \%$ were familiar with PGx [19].

Pharmacogenetics is a crucial part of any healthcare system. Some Arab nations, particularly Gulf countries, have initiated the implementation of special research programs in favour of PGx, such as the Saudi human genome program (SHGP) [41]. However, in Syria, limited resources, restricted genomic studies, economic embargo and sanctions are currently the major obstacles to the implementation of PGx testing in our country.

\section{Strengths and limitations}

This study is the first to assess knowledge, and attitude towards PGx amongst physicians and pharmacists in Syria. It is one of a few studies that added some data to the limited existing literature in the region. In spite of the weak knowledge, a positive attitude was marked amongst respondents in general towards learning more, participating in this field, and in raising awareness of PGx. Also, the very high percentage of the questionnaire completion is a strength, which may indicate the importance of this topic to the respondents and that they were interested in sharing their opinions.

Our survey consisted of 26 questions, some of which were challenging, precise, and some had choices that demanded particular concentarion. Therfore, particepants may felt overwhelmed and lost concentarion by time, this may be considered a weakness point in our report. The low participation rate also may be considered as a limitation.

\section{Conclusion}

This study revealed poor knowledge of PGx in general. Also, the low level of PGx awareness especially amongst physicians reflects the urgent need to improve medical curricula in Syrian universities for both graduate and undergraduate students, and emphasizes the importance of developing learning tools on PGx for clinicians and pharmacists. We stress on the role of education, training, and conducting genotyping studies on the Syrian population; for future implementation of specific PGx testing and guidelines suitable for our society.

\section{Abbreviations}

PM: Personalized medicine.; PGX: Pharmacogenetics.; CPIC: Clinical Pharmacogenetics Implementation Consortium.; PKS: Percentage knowledge assessment score.; U-PGx: European Ubiquitous Pharmacogenomics.; SHGP: Saudi human genome program.

\section{Supplementary Information}

The online version contains supplementary material available at https://doi. org/10.1186/s12913-021-07040-9.

Additional file 1.

Additional file 2 .

\section{Acknowledgments}

The authors would like to thank all respondents for taking part in this study. We also acknowledge Dr. Imad Alkadi who we lost during Covid19 epidemic and Ms. Marah Marrawi for their assistance with statistical analyses.

\section{Authors' contributions}

Lina Albitar and Ghalia Abou Alchamat contributed equally in literature review, questionnaire design, collecting data, writing and revising the manuscript.

\section{Funding}

Not applicable.

\section{Availability of data and materials}

The data that support the findings of this study are available from the corresponding author, upon reasonable request.

\section{Declarations}

\section{Ethics approval and consent to participate}

This study was approved by both Damascus University and Arab International University, Damascus, Syria. All methods were carried out in accordance with Declaration of Helsinki. All participants were fully informed about the study, and informed consent was obtained from all of them.

\section{Consent for publication}

Not applicable.

\section{Competing interests}

No conflict of interest is associated with this publication.

\section{Author details}

'Department of Pharmaceutics, Faculty of Pharmacy, Arab International University, Damascus, Syria. ${ }^{2}$ Department of Biology, Faculty of Science, Damascus University, Damascus, Syria.

Received: 12 May 2021 Accepted: 10 September 2021

Published online: 01 October 2021

\section{References}

1. Vogenberg FR, Barash Cl, Pursel M. Personalized medicine: part 1: evolution and development into theranostics. Pharm Therapeutics. 2010;35(10):560-76.

2. Zaza G, Granata S, Mangino M, Grandaliano G, Paolo F. Dalla farmacogeNetlca alla farmacogeNomlca: la Nuova era Della terapla perSoNallzzata IN Nefrologla. G Ital Nefrol. 2010;27(4):353-66.

3. López-López M, Guerrero-Camacho JL, Familiar-López IM, Jung-Cook H, Corona-Vázquez T, Alonso-Vilatela ME. Farmacogenómica: búsqueda de la terapia personalizada. Rev Neurol. 2004;39(11):1063-71. https://doi.org/10.33 588/rn.3911.2004276.

4. Trent RJ. Pathology practice and pharmacogenomics. Pharmacogenomics. 2010;11(1):105-11. https://doi.org/10.2217/pgs.09.150.

5. Mini E, Nobili S. Pharmacogenetics: implementing personalized medicine. Clin Cases Miner Bone Metab. 2009;6(1):17-24.

6. Dervieux T, Bala MV. Overview of the pharmacoeconomics of pharmacogenetics. Pharmacogenomics. 2006;7(8):1175-84. https://doi.org/1 0.2217/14622416.7.8.1175.

7. Gervasini G, Benítez J, Carrillo JA. Pharmacogenetic testing and therapeutic drug monitoring are complementary tools for optimal individualization of drug therapy. Eur J Clin Pharmacol. 2010;66(8):755-74. https://doi.org/10.1 007/s00228-010-0857-7

8. Gogtay NJ, Thatte UM, Ravi R, Bose D. Personalizing medicine with pharmacogenetics and pharmacogenomics. In Clinical Molecular Medicine. Academic Press. 2020. p. 521-34.

9. Klein ME, Parvez MM, Shin JG. Clinical implementation of pharmacogenomics for personalized precision medicine: barriers and solutions. J Pharm Sci. 2017;106(9):2368-79. https://doi.org/10.1016/j.xphs.2 017.04.051.

10. Cecchin E, De Mattia E, Ecca F, Toffoli G. Host genetic profiling to increase drug safety in colorectal cancer from discovery to implementation. Drug Resist Updat. 2018;39:18-40. https://doi.org/10.1016/j.drup.2018.07.001. 
11. Harmsze AM, Deneer VH, Maitland-van der Zee AH, de Boer A, Klungel OH. Genetische variaties beïnvloeden effectiviteit en veiligheid van geneesmiddelen [genetic variations affect drug safety and efficacy]. Ned Tijdschr Geneeskd. 2010;154(28):1329-33.

12. Palmirotta R, Carella C, Silvestris E, Cives M, Stucci SL, Tucci M, et al. SNPs in predicting clinical efficacy and toxicity of chemotherapy: walking through the quicksand. Oncotarget. 2018;9(38):25355. https://doi.org/10.18632/ oncotarget.25256.

13. Botticelli A, Scagnoli S, Roberto M, Lionetto L, Cerbelli B, Simmaco M, et al. 5-fluorouracil degradation rate as a predictive biomarker of toxicity in breast cancer patients treated with capecitabine. J Oncol Pharm Pract. 2020;26(8): 1836-42. https://doi.org/10.1177/1078155220904999.

14. Karachaliou N, Moreno MD, Sosa AE, Santarpia M, Lazzari C, Capote AR, et al. Using genetics to predict patient response to platinum-based chemotherapy. Expert Rev Precision Med Drug Dev. 2017;2(1):21-32. https:// doi.org/10.1080/23808993.2017.1298969.

15. Etienne-Grimaldi MC, Boyer JC, Thomas F, Quaranta S, Picard N, Loriot MA et al. UGT $1 \mathrm{~A} 1$ genotype and irinotecan therapy: general review and implementation in routine practice. Fundam Clin Pharmacol. 2015;29(3): 219-37. https://doi.org/10.1111/fcp.12117.

16. Bruera G, Ricevuto E. Pharmacogenomic assessment of patients with colorectal cancer and potential treatments. Pharmacogenomics Pers Med. 2020;13:601Published 2020 Nov 16. https://doi.org/10.2147/PGPM.S253586.

17. Jarrar $Y$, Mosleh R, Hawash M, Jarrar Q. Knowledge and attitudes of pharmacy students towards pharmacogenomics among universities in Jordan and west bank of Palestine. Pharmacogenomics Pers Med. 2019;12: 247-55. https://doi.org/10.2147/PGPM.S222705

18. Bagher AM, Neamatallah T, Balto G, Almikhy L, Almutairi SS, Abushal MO, et al. Knowledge, perception, and confidence of hospital pharmacists toward pharmacogenetics in Jeddah, Kingdom of Saudi Arabia. Saudi Pharmaceutical J. 2021;29(1):53-8. https://doi.org/10.1016/j.jsps.2020.12.006.

19. Rahawi S, Naik H, Blake KV, Obeng AO, Wasserman RM, Seki Y, et al. Knowledge and attitudes on pharmacogenetics among pediatricians. J Hum Genet. 2020;65(5):437-44. https://doi.org/10.1038/s10038-020-0723-0.

20. Albassam A, Alshammari S, Ouda G, Koshy S, Awad A. Knowledge, perceptions and confidence of physicians and pharmacists towards pharmacogenetics practice in Kuwait. PLoS One. 2018;13(9):e0203033. https://doi.org/10.1371/journal.pone.0203033.

21. Obara T, Abe S, Satoh M, Ubeda SR, Yoshimachi S, Goto T. Awareness regarding clinical application of pharmacogenetics among Japanese pharmacists. Pharmacogenom Pers Med. 2015;8:35. https://doi.org/10.2147/ PGPM.S71813.

22. Just KS, Steffens M, Swen JJ, Patrinos GP, Guchelaar HJ, Stingl JC. Medical education in pharmacogenomics-results from a survey on pharmacogenetic knowledge in healthcare professionals within the European pharmacogenomics clinical implementation project ubiquitous pharmacogenomics (U-PGX). Eur J Clin Pharmacol. 2017;73(10):1247-52. https://doi.org/10.1007/s00228-017-2292-5.

23. Rahma AT, Elsheik M, Ali BR, Elbarazi I, Patrinos GP, Ahmed LA, et al. Knowledge, attitudes, and perceived barriers toward genetic testing and pharmacogenomics among healthcare Workers in the United Arab Emirates: a cross-sectional study. J Pers Med. 2020;10(4):216. https://doi.org/10.3390/ jpm10040216.

24. Elewa H, Alkhiyami D, Alsahan D, Abdel-Aziz A. A survey on the awareness and attitude of pharmacists and doctors towards the application of pharmacogenomics and its challenges in Q Atar. J Eval Clin Pract. 2015; 21(4):703-9. https://doi.org/10.1111/jep.12372.

25. Karas Kuželički N, Prodan Žitnik I, Gurwitz D, Llerena A, Cascorbi I, Siest S, et al. Pharmacogenomics education in medical and pharmacy schools: conclusions of a global survey. Pharmacogenomics. 2019;20(9):643-57. https://doi.org/10.2217/pgs-2019-0009.

26. Green JS, O'Brien TJ, Chiappinelli VA, Harralson AF. Pharmacogenomics instruction in US and Canadian medical schools: implications for personalized medicine. Pharmacogenomics. 2010;11(9):1331-40. https://doi. org/10.2217/pgs.10.122.

27. Higgs JE, Andrews J, Gurwitz D, Payne K, Newman W. Pharmacogenetics education in British medical schools. Genomic Med. 2008;2(3):101-5. https:// doi.org/10.1007/s11568-009-9032-6.

28. McCullough KB, Formea CM, Berg KD, Burzynski JA, Cunningham JL, Ou NN, et al. Assessment of the pharmacogenomics educational needs of pharmacists. Am J Pharm Educ. 2011;11(3):75(3). https://doi.org/10.5688/a jpe75351.

29. Stanek EJ, Sanders CL, Taber KJ, Khalid M, Patel A, Verbrugge RR, et al. Adoption of pharmacogenomic testing by US physicians: results of a nationwide survey. Clin Pharmacol Therapeutics. 2012;91(3):450-8. https:// doi.org/10.1038/clpt.2011.306.

30. Mai Y, Mitropoulou C, Papadopoulou XE, Vozikis A, Cooper DN, Van Schaik $\mathrm{RH}$, et al. Critical appraisal of the views of healthcare professionals with respect to pharmacogenomics and personalized medicine in Greece. Pers Med. 2014;11(1):15-26. https://doi.org/10.2217/pme.13.92.

31. Bannur Z, Bahaman S, Salleh MZ, Teh LK. Pharmacogenomics based practice in Malaysia: the attitude, knowledge and adoption by the healthcare professionals. IIUM Medical J Malaysia. 2014;13(1). https://doi.org/10.31436/ IMJM.V13|1.491.

32. Nagy M, Lynch M, Kamal S, Mohamed S, Hadad A, Abouelnaga S, et al. Assessment of healthcare professionals' knowledge, attitudes, and perceived challenges of clinical pharmacogenetic testing in Egypt. Pers Med. 2020; 17(4):251-60. https://doi.org/10.2217/pme-2019-0163.

33. Muzoriana N, Gavi S, Nembaware V, Dhoro M, Matimba A. Knowledge, attitude, and perceptions of pharmacists and pharmacy students towards pharmacogenomics in Zimbabwe. Pharmacy. 2017;5(3):36. https://doi.org/1 0.3390/pharmacy5030036.

34. Mills R, Haga SB. Clinical delivery of pharmacogenetic testing services: a proposed partnership between genetic counselors and pharmacists. Pharmacogenomics. 2013;14(8):957-68. https://doi.org/10.2217/pgs.13.76.

35. Williams MS. Genomic medicine implementation: learning by example. Am J Med Genet. 2014;166(1):8-14.

36. Bank PC, Swen JJ, Guchelaar HJ. A nationwide survey of pharmacists' perception of pharmacogenetics in the context of a clinical decision support system containing pharmacogenetics dosing recommendations. Pharmacogenomics. 2017;18(3):215-25. https://doi.org/10.2217/pgs-20160138.

37. Algahtani M. Knowledge, perception, and application of pharmacogenomics among hospital pharmacists in Saudi Arabia. Risk Manag Healthcare Policy. 2020;13:1279-91. https://doi.org/10.2147/RMHP.S267492.

38. Da P, SI N, Bp S, Knowledge TS. Awareness and attitude of pharmacists toward pharmacogenetic practice: perspective of community and hospital in Yogyakarta, Indonesia J Commun Med Health Educ 2017;7(06):1-0. doi: https://doi.org/10.4172/2161-0711.1000568.

39. AlEjielat R, Ejielat Z, Andrawes S, Mhaidat NM. An evaluation of the knowledge, opinions, expectations and concerns toward pharmacogenomics among Jordanian pharmacists. Pers Med. 2016;13(2): 143-54. https://doi.org/10.2217/pme.15.50.

40. Abdela OA, Bhagavathula AS, Gebreyohannes EA, Tegegn HG. Ethiopian health care professionals' knowledge, attitude, and interests toward pharmacogenomics. Pharmacogenom Personal Medicine. 2017;10:279-85. https://doi.org/10.2147/PGPM.S145336.

41. Abu-Elmagd M, Assidi M, Schulten HJ, Dallol A, Pushparaj PN, Ahmed F, et al. Individualized medicine enabled by genomics in Saudi Arabia. BMC Med Genet. 2015;8(1):1-7. https://doi.org/10.1186/1755-8794-8-S1-S3.

\section{Publisher's Note}

Springer Nature remains neutral with regard to jurisdictional claims in published maps and institutional affiliations.

Ready to submit your research? Choose BMC and benefit from:

- fast, convenient online submission

- thorough peer review by experienced researchers in your field

- rapid publication on acceptance

- support for research data, including large and complex data types

- gold Open Access which fosters wider collaboration and increased citations

- maximum visibility for your research: over $100 \mathrm{M}$ website views per year

At BMC, research is always in progress.

Learn more biomedcentral.com/submissions 